\title{
A beszédtempó és az artikulációs tempó gyermekek és kamaszok beszédében a beszédtípus és a mértékegység függvényében*
}

\section{Bevezetés}

A beszéd temporális jellemzői egyrészt megmutatják az artikulációs mozgások gyorsaságát, másrészt árulkodnak a beszédtervezési és önellenőrzési folyamatokról is (Gósy 2004). Több beszéd- és nyelvi zavar elsődlegesen a tempó zavarával áll öszszefüggésben, így például a dadogás, a hadarás, avagy a dizartria is (Ryan 1992; St. Louis-Schulte 2011; Tumanova et al. 2011; Chon et al. 2012). A szupraszegmentális szint temporális jellemzői közé tartoznak az artikulációs tempó, a beszédtempó és a szünettartás sajátosságai. Az artikulációs tempó elsősorban a beszédszervek működésének gyorsaságától függ. Értékét nem, illetve csak kis mértékben befolyásolják a magasabb szintü nyelvi folyamatok (Walker et al. 1992). Kiszámítása úgy történik, hogy a nyelvi jelek számát elosztjuk a kiejtésükre fordított idővel (a jelidővel). A beszédtempót ezzel szemben nagymértékben meghatározzák a beszédtervezési folyamatok, a kiszámításakor figyelembe vesszük a szünettartást is (a nyelvi jelek számát elosztjuk a teljes beszédidővel, vö. Gósy 2004).

A beszéd temporális sajátosságait számos tényező befolyásolja, ezek közül két fontos tényező a beszélő életkora (gyermekekre: pl. Laczkó 1991; Gósy 1997; Amir-Grinfeld 2011; Horváth 2013; 2016; Neuberger 2014; Vakula-Krepsz 2018; Gyarmathy-Horváth 2019; Vakula 2020) és a beszédtípus (Markó 2005, 2014; Váradi 2010; 2011; Bóna 2015). Mindkét tényező hatását számos tanulmányban elemezték már, ugyanakkor a gyermekek beszédének temporális jellemzőivel foglalkozó kutatások vagy csak az egyik paraméterre (pl. csak az artikulációs tempóra vagy a szünettartásra) fókuszálnak, vagy főképp a fiatalabb életkorokban (általában 6 éves korig) vizsgálják a beszédet. A különbözö kutatásokban többféle beszédtípust is vizsgálnak, de általában vagy csak az artikulációs tempót, vagy csak a szünettartást vetik össze a beszédtípusok és az életkorok között (Deputy et al. 1982). Kevés tehát az olyan elemzés a gyermeki beszédben, amelyik a beszédtempót is vizsgálná különböző életkorokban és különböző beszédtípusokban összevetve.

A gyermeknyelvvel kapcsolatban a kutatók egyetértenek abban, hogy az életkor előrehaladtával a beszédtempó gyorsul, jóllehet ez a gyorsulás nem egyenletes (Walker-Archibald 2006; Amir-Grinfeld 2011; Horváth 2016), és az iskolai évek alatt is tart (Neuberger 2014; Aoyama et al. 2016). Az artikulációs tempó gyorsulása 13 éves kor után éri el a felnőttekhez hasonló szintet, 17 éves korig még fontos változások történnek a tempót tekintve is (Laczkó 2009; Amir-Grinfeld 2016). Magyar gyermekek beszédét vizsgálva Neuberger (2014) azt találta, hogy a beszédtempóban szótag/s-ot számítva szignifikáns a különbség a 13 évesek, illetve a 6, 7 és 9 évesek között, ugyanakkor a 6, 7, 9 és 11 évesek beszédtempója nem mutatott szignifikáns

\footnotetext{
* A kutatást a Nemzeti Kutatási, Fejlesztési és Innovációs Hivatal K-120234 számú pályázata és a Tématerületi Kiválósági Program támogatta.
} 
különbséget. Horváth (2016) az artikulációs tempót vizsgálta 7, 8 és 9 éveseknél, és szignifikáns különbséget talált mindegyik csoport között.

A tempóváltozás egyrészt biológiai tényezőknek, másrészt tanult készségeknek köszönhető. Biológiai tényezők például a beszédszervek növekedése vagy a neurológiai és neuromotoros érés (pl. Vorperian-Kent 2007; Balázs-Bóna 2016); míg a tanult készségekhez tartozik a motoros tanulás, a motoros programozás, tervezés, illetve a nyelvi tudáshoz, így a szemantikai, lexikai és fonológiai szinthez való hozzáférés (pl. Nip-Green 2013). Ezzel összefüggésben kimutatták, hogy a munkamemória teljesítménye és a beszédsebesség is összefüggésben állnak egymással: az idősebb gyermekek beszédtempóját pozitívan befolyásolja a munkamemória tárolókapacitásának a növekedése, illetve a hosszú távú memória jobb müködése is (Roodenrys-HulmeBrown 1993; Henry 1994).

Amint arról már szó volt, az életkor mellett a beszédtípus is befolyásolja a tempóértékeket, hiszen a különböző beszédtípusok eltérő beszédtervezést igényelnek (Krepsz 2016). Az eltérő beszédtervezés megjelenhet a szünettartásban és a tempóértékekben is (Markó 2005; Jacewicz et al. 2010; Bóna 2015; Redford 2015). Magyar anyanyelvű fiatal felnőttek és idősek beszédét elemezve azt találták (Bóna 2015), hogy a beszédtípus szignifikánsan befolyásolja a beszédtempót, a szünetek gyakoriságát és arányát, illetve a szünetek átlagos időtartamát. A leglassabb tempó és a legtöbb, leghosszabb szünet a tartalom-visszamondásban fordult elő, míg a legkevesebb szünet a társalgásra volt jellemző. Markó (2005) spontán narratívákat, képleírást és társalgást hasonlított össze. Az eredményei szerint a képleírásban lassabb, a társalgásban gyorsabb tempóértékek voltak adatolhatók a spontán narratívákhoz képest. A spontán beszéd és a felolvasás összehasonlításakor pedig az utóbbi bizonyult gyorsabb tempójúnak (Váradi 2010; Markó 2014).

Több vizsgálatban elemezték azt, hogy együttesen hogyan hatnak az életkor és a különböző beszédtípusok az artikuláció sebességére különböző életkorú gyermekeknél. Walker és Archibald (2006) egy longitudinális kutatásban azt vizsgálták, hogy hogyan változik az artikulációs tempó angol anyanyelvü gyermekeknél 4, 5 és 6 éves korban, és hogyan befolyásolja mindezt a beszédtípus, a közlés hossza és a beszélö neme. A négy beszédtípus a következő volt: spontán történetmesélés képsorok alapján, mondatok utánmondása, mondóka elmondása, illetve egy mondat ötszöri elismétlése. Ezek az eredményeik is igazolták, hogy az artikulációs tempó növekedése nem lineáris az életkorral. A tempó variabilitása sem csökkent az életkorral, minden életkorban nagy egyéni különbségek voltak adatolhatók. A vizsgált faktorok közül a beszédtípus hatását sikerült csak igazolni, míg a nem és a közlés hossza nem volt hatással az artikulációs tempóra. Amir és Grinfeld (2016) 140 gyermek artikulációs tempóját elemezte hét életkori csoportban: 3, 5, 7, 9, 11, 13, 17 éves korban (mindegyik életkori csoportban 20 gyermek volt). Az életkorok mellett két beszédtípust vetettek össze: spontán társalgást és képleírást.

A tempóértékeket különböző mértékegységekkel szokták megadni. A hazai gyakorlatban a legelterjedtebb a hang/s-os érték használata, de előfordul a szó/perc is (Gósy 2004). A nemzetközi szakirodalom főképp a szótag/s-os vagy a szó/perces értéket használja (vö. Amir-Grinfeld 2016). A hang/s használatát a magyar szakiro- 
dalomban általában azzal indokolják, hogy nagyon változatos lehet a szótagszerkezet és a szóhosszúság is, egy szónak számítanak például az is és a mértékegységekben, egy szótagnak a tartsd és az ül szavak (Bóna 2009). Nyilvánvaló tehát, hogy a szavak és a szótagok egységként való alkalmazása csak egy kevésbé pontos, megközelítő értéket mutathat. A hang/s-os érték kiszámításánál ugyanakkor problémát okozhat az, ha a vizsgált beszédprodukció pontos szegmentálása a gyors tempó vagy a pontatlan artikuláció miatt lehetetlen. Ilyenkor nem lehet a beszédhangokat azonosítani, azaz a hang/ másodperces érték kiszámítása nem lehetséges. Erre egyes kutatásokban a fonéma/sos értéket használják, azaz nem a valóban elhangzott hangokat számolják meg, hanem a szavakat alkotó fonémákét. Ez viszont azt jelenti, hogy az artikuláció sebességéröl megint csak közelítő értéket kapunk. Bóna (2009) tipikus beszédü felnőttek beszédében számította ki négyféleképpen a beszéd- és artikulációs tempót. Eredményei szerint a hang/s-ban és fonéma/s-ban megadott értékek között elhanyagolható volt a különbség, míg a szótag/s-os és a szó/perces tempóértékek függetlenek voltak a hang/s-ban kifejezett tempóértékektől, vagyis nem annak arányában jelennek meg. Voltak olyan beszélők, akiknek a szó/percben mért beszédtempójuk azonos volt, míg a másik három tempóértékben nagy különbséget mutattak. Egy másik beszélö, akinél a leglassabb tempó volt adatolható a hang/s-os, fonéma/s-os és a szótag/s-os mértékegység szerint, csak a második leglassabb beszédü volt a szó/perces értékek alapján.

Bár a szóhosszúság, az artikulációs pontossága, avagy a rövidülési tendenciák miatt nincs egyértelmű összefüggés a mértékegységek között, többen megkísérelték matematikai módszerekkel átváltani őket. Angol anyanyelvü felnőttek beszédében a szavak és a szótagok száma közötti arányt 1,5 szótag/szóban (Johnson et al. 1963), illetve 1,4 szótag/szóban (Andrews-Ingham 1971) határozták meg. A fentebb említett okok miatt ez az átváltás is problematikus lehet, a gyermekek esetében pedig nem alkalmazható. A kutatások ugyanis azt találták, hogy angol anyanyelvü tipikus fejlődésű gyermekeknél 3 és 8 éves kor között a szavak szótagszáma szignifikánsan megnő (Flipsen 2006). Több, gyermekekkel végzett kutatásban jutottak arra az eredményre, hogy a tempóértékek az egyik méröszám esetében szignifikáns különbségeket mutattak a különböző életkori csoportok között, míg más mérőszámok esetén nem volt szignifikáns a különbség (Hall et al. 1999; Flipsen 2002; Neuberger 2014; Amir-Grinfeld 2016).

A fentebb említett kutatások tehát megerősítik a temporális paraméterek változásait, de vagy nem foglalkoznak a beszédtípus hatásával, vagy csak egy szük életkori sávban vizsgálódnak, vagy egy paramétert elemeznek a különböző beszédtípusok függvényében. A jelen kutatás kérdései a következők: 1) Hogyan változik a beszédtempó és az artikulációs tempó az életkor és a beszédtípus függvényében 6 és 17 éves kor között? 2) Mindegyik életkorban ugyanaz a beszédtípus lesz-e a leggyorsabb és a leglassabb? 3) A különböző mértékegységek azonos eredményeket mutatnak-e a beszédtempót és az artikulációs tempót illetően?

Hipotéziseink a következők voltak: 1) Az életkor előrehaladtával mindegyik beszédtípusban nő a beszédtempó és az artikulációs tempó is. 2) A tempóértékeket különböző módon befolyásolják a beszédtípusok a kisebb gyermekeknél és a kamaszoknál. A két fiatalabb életkori csoportban a képsor alapján való történetmesélés 
lesz a leggyorsabb, míg a kamaszoknál a spontán narratíva. 3) Az eltérő mértékegységekben megadott tempóértékek különböző eredményeket mutatnak: a szótag/s-os és a hang/s-os tempóértékek esetén hasonló statisztikai adatokat kapunk, míg a szó/ perces értékek más különbségeket fognak mutatni.

\section{Módszertan}

\subsection{Adatközlők}

A vizsgálathoz 80 hangfelvételt választottunk ki a GABI beszédadatbázisból (Bóna 2017). A beszélök négy korcsoportból kerültek ki: 6 évesek, 9 évesek, 13 évesek és 17 évesek voltak. Mindegyik csoportban 10 fiú és 10 lány felvétele szerepelt. Minden beszélö magyar anyanyelvü, ép halló, tipikus beszédfejlődésü volt. Azért választottuk ezt a négy életkori csoportot a vizsgálathoz, mert mindegyik életkor fontos állomása az elsőnyelv-elsajátításnak. A 6 éves kor az iskolába lépés időszaka, a 9 éves kor az írott nyelv elsajátításának a megszilárdulása, 13 éves korban az artikuláció már felnőttszerü (pl. Auszmann 2016), a 17 éves kor pedig a kamaszkor vége.

\subsection{Anyag}

A felvételek csendesített helyiségben az adatközlök megszokott környezetében készültek. A vizsgálatban három beszédtípust elemeztünk, ezek különböző nehézségüek voltak: 1) interjúhelyzetben rögzített spontán beszédet (az adatközlők a saját életükről meséltek); 2) történetmesélést (az adatközlők egy hat képből álló képsorozat alapján meséltek el egy történetet); 3) tartalomösszegzést (az adatközlők feladata az volt, hogy egy hallott történetet azonnal meséljenek vissza a lehető legpontosabban). 1) Az interjú során a beszélő maga találta ki a mondandója tartalmát és formáját az interjúkészítő kérdéseinek megfelelően, és elegendő ideje volt a válasz megfogalmazására. A jelen vizsgálatban a téma könnyü volt, nem igényelt különösebb gondolkodást, illetve specifikus ismereteket. Az interjú során csak akkor került sor újabb kérdésre, amikor a gyermek egy adott kérdésről már nem tudott vagy nem kívánt többet beszélni. Voltak gyermekek, akik egy-egy kérdésre hosszan, összefüggően válaszoltak, ilyenkor valódi spontán narratíva jött létre. Voltak azonban olyan gyermekek is, akik csak néhány mondatos (néha egymondatos) választ adtak, majd újabb (segítő) kérdést kellett feltenni nekik. Ezért ezt a beszédtípust a továbbiakban interjúként nevezzük meg. 2) A történetmesélés során az adatközlőknek egy hat képből álló történetet kellett elmesélniük. A képsor - a képregényektől megszokott formában - fekete-fehér rajzként lett bemutatva. Az elmesélendő történet a gyermekek számára is könnyen értelmezhető volt. Ebben a beszédtípusban a beszélőknek elöbb fel kellett ismerniük és értelmezniük a képeken bemutatott történetet, majd a struktúra ismeretében kellett nyelvi formába önteniük. A tartalom tehát adott volt, a feladatként a szöveg megfogalmazását kapták. 3) A tartalomösszegzés során az adatközlők először egy történetet hallgattak meg, majd ezt a lehető legpontosabban vissza kellett mesélniük. A tartalomösszegzés sikerességéhez több nyelvi és nyelvtől 
független folyamat együttes jó müködésére van szükség, ezek a következők: beszédmegértés, figyelem, rövid és hosszú távú memória, illetve narratív kompetencia (Juncos-Rabadán-Pereiro 1999).

Minden gyermektől mintegy hárompercnyi spontán narratívát elemeztünk, ami mindegyik életkorban több mint 400 szótagnyi közlést jelentett. A másik két beszédtípus hossza a gyermektől is függött, különösen a képsorról való mesélésben voltak nagy egyéni különbségek, de átlagosan mindegyik életkorban és beszédtípusban minimum 150 szótagnyi közlést elemeztünk. A legrövidebb történeteket a 17 évesek hozták létre a képsor alapján.

\subsection{Módszer}

A beszédszakaszokat (két szünet közötti nyelvi jelek) a Praat szoftverrel annotáltuk (Boersma-Weenink 2008). Egy szkript segítségével automatikusan megmértük a beszédszakaszok hosszát és a szünetek időtartamát, majd kiírattuk egy Excel-táblázatba a hangok, szótagok és szavak számát. Ezután kiszámítottuk a beszédtempót és az artikulációs tempót három mértékegység szerint is: hang/s-ban, szótag/s-ban és szó/percben. Az adatokat az életkori csoportok és a beszédtípusok függvényében vetettük össze.

A statisztikai elemzést az SPSS 20.0 szoftverrel végeztük el 95\%-os konfidenciaszinten. Az életkori csoportok közötti összevetést UNIANOVA-val és Tukey post hoc teszttel, az ugyanazon életkori csoportokban adatolt tempóértékeket a különböző beszédtípusok között az ismétléses ANOVA-val és páronkénti összehasonlítással vetettük össze.

\section{Eredmények}

A beszédtempó és az artikulációs tempó értékei az 1. és a 2. táblázatban olvashatók az életkor, a beszédtípus és a mértékegység függvényében.

1. táblázat. A beszédtempó az életkor, a beszédtípus és a mértékegység függvényében (átlag és szórás)

\begin{tabular}{|l|l|l|l|l|l|}
\hline & Mértékegység & 6 évesek & \multicolumn{1}{|c|}{ 9 évesek } & \multicolumn{1}{|c|}{ 13 évesek } & \multicolumn{1}{|c|}{ 17 évesek } \\
\hline \multirow{4}{*}{ Interjú } & hang/s & $5,8(1,2)$ & $6,6(1,1)$ & $7,2(2,7)$ & $9,2(1,3)$ \\
\cline { 2 - 6 } & szótag/s & $2,5(0,5)$ & $2,8(0,5)$ & $3,5(0,7)$ & $3,9(0,6)$ \\
\cline { 2 - 6 } & szó/perc & $79,6(18,5)$ & $86,4(17,1)$ & $109,3(29,4)$ & $107,4(20,5)$ \\
\hline \multirow{3}{*}{$\begin{array}{c}\text { Történet képsor } \\
\text { alapján }\end{array}$} & hang/s & $5,3(1,2)$ & $6,3(0,9)$ & $6,4(2,4)$ & $8,4(1,2)$ \\
\cline { 2 - 6 } & szótag/s & $2,4(0,5)$ & $2,8(0,4)$ & $3,3(0,7)$ & $3,7(0,5)$ \\
\cline { 2 - 6 } & szó/perc & $79,7(17,8)$ & $92,5(15,6)$ & $105,7(24,7)$ & $103,2(18,3)$ \\
\hline \multirow{2}{*}{$\begin{array}{c}\text { Tartalom- } \\
\text { összegzés }\end{array}$} & hang/s & $5,5(1,2)$ & $6,5(1,6)$ & $6,3(2,3)$ & $7,6(1,6)$ \\
\cline { 2 - 6 } & szótag/s & $2,4(0,5)$ & $2,8(0,7)$ & $3,1(0,5)$ & $3,3(0,7)$ \\
\cline { 2 - 6 } & szó/perc & $78,6(14,6)$ & $89,8(23,4)$ & $102,1(34,7)$ & $91,4(20,0)$ \\
\hline
\end{tabular}


2. táblázat. Az artikulációs tempó az életkor, a beszédtípus és a mértékegység függvényében (átlag és szórás)

\begin{tabular}{|l|l|l|l|l|l|}
\hline & Mértékegység & \multicolumn{1}{|c|}{ 6 évesek } & \multicolumn{1}{|c|}{ 9 évesek } & \multicolumn{1}{|c|}{ 13 évesek } & \multicolumn{1}{|c|}{ 17 évesek } \\
\hline \multirow{3}{*}{ Interjú } & hang/s & $9,0(1,1)$ & $10,1(1,4)$ & $10,3(3,5)$ & $11,9(1,0)$ \\
\cline { 2 - 6 } & szótag/s & $3,8(0,4)$ & $4,3(0,6)$ & $5,0(0,6)$ & $5,4(0,5)$ \\
\cline { 2 - 7 } & szó/perc & $122,3(17,9)$ & $131,3(21,5)$ & $156,5(35,2)$ & $148,5(20,9)$ \\
\hline \multirow{3}{*}{$\begin{array}{c}\text { Történet képsor } \\
\text { alapján }\end{array}$} & hang/s & $8,4(1,0)$ & $9,4(1,1)$ & $9,5(3,1)$ & $11,0(1,2)$ \\
\cline { 2 - 7 } & szótag/s & $3,8(0,5)$ & $4,3(0,5)$ & $4,9(0,6)$ & $5,1(0,5)$ \\
\cline { 2 - 6 } & szó/perc & $126,7(17,2)$ & $139,2(18,7)$ & $169,4(54,2)$ & $144,6(23,8)$ \\
\hline \multirow{3}{*}{$\begin{array}{c}\text { Tartalom- } \\
\text { összegzés }\end{array}$} & hang/s & $8,3(1,3)$ & $10,0(1,2)$ & $9,4(3,2)$ & $10,5(1,1)$ \\
\cline { 2 - 6 } & szótag/s & $3,7(0,6)$ & $4,3(0,6)$ & $4,6(0,7)$ & $4,9(0,5)$ \\
\cline { 2 - 6 } & szó/perc & $118,1(11,3)$ & $139,1(17,2)$ & $151,3(43,7)$ & $137,1(20,7)$ \\
\hline
\end{tabular}

\subsection{Interjú}

Általánosságban megfigyelhető, hogy mind a beszédtempó, mind az artikulációs tempó nőtt az idősebb életkori csoportokban. Ez a növekedés azonban nem volt egyenletes, és különböző eredmények születtek az eltérő mértékegységek esetében. A leglassabb tempóértékek a 6 éveseknél, a leggyorsabbak a 17 éveseknél voltak mérhetők a hang/s és a szótag/s esetén, míg a szó/perces értéket tekintve a 13 éveseknél mértük a leggyorsabb tempóértékeket.

A statisztikai elemzés szerint mindhárom mértékegység szerint szignifikáns különbség volt a beszédtempóban és az artikulációs tempóban is az életkori csoportok között [a beszédtempó esetén hang/s: $F(3,77)=14,161 ; p<0.001 ; \eta^{2}=0.359$; szótag/s: $F(3,77)=25,609 ; p<0,001 ; \eta^{2}=0,503$; szó/perc: $F(3,77)=9,306 ; p<0.001$; $\eta^{2}=0.269$; az artikulációs tempó esetén hang/s: $F(3,77)=6,875 ; p<0,001 ; \eta^{2}=$ 0,213 ; szótag/s: $F(3,77)=35,957 ; p<0.001 ; \eta^{2}=0.578$; szó/perc: $F(3,77)=7,983$; $\left.p<0,001 ; \eta^{2}=0,240\right]$. Ugyanakkor a Tukey post hoc test szerint a beszédtempó a hang/s-os értéket tekintve csak a 17 évesek és a többi életkori csoport között különbözött szignifikánsan $(p<0,001$; illetve a 13 éveseknél $p=0,002)$, míg a szótag/s-os és a szó/perces érték esetén a 6 és a 13 évesek $(p<0,001)$, a 6 és 17 évesek $(p<0,001)$, a 9 és 13 évesek (szótag/s: $p=0,002$; szó/perc: $p=0,008$ ), illetve a 9 és 17 évesek (szótag/s: $p<0,001$; szó/perc: $p=0,016$ ) között volt szignifikáns a különbség. Az artikulációs tempóban a hang/s-os értéket tekintve a 17 évesek és a $6(p<0,001)$, illetve $9(p=0,042)$ évesek között, a szótag/s-os és a szó/perces értéket tekintve a 6 és 13 évesek $(p<0,001)$, illetve a 6 és 17 évesek $(p<0,001$ és $p=0,007)$, a 9 és 13 évesek $(p<0,001$ és $p=0,010)$, és a csak a szótag/s-os értéket tekintve még a 9 és 17 évesek $(p<0,001)$ között volt szignifikáns a különbség.

\subsection{Történetmesélés képsor alapján}

A második beszédtípusban is megfigyelhető volt a tempóértékek növekedése az életkor elörehaladtával. Ebben az esetben is eltérés volt a különböző mértékegysé- 
gekben megadott tempóértékek között: a leglassabb beszéd- és artikulációs tempót mindhárom érték szerint a 6 évesek produkálták, míg a leggyorsabbat a hang/s-os és a szótag/s-os mértékegység szerint a 17 évesek, a szó/perc szerint a 13 évesek.

A statisztikai elemzés szerint szignifikáns különbség volt a csoportok között mind a beszédtempóban, mind az artikulációs tempóban mindhárom tempóértéket tekintve [a beszédtempó esetén hang/s: $F(3,77)=13,601 ; p<0,001 ; \eta^{2}=0,349$; szótag/s: $F(3,77)=19,848 ; p<0,001 ; \eta^{2}=0,439$; szó/perc: $F(3,77)=7,479 ; p<0,001$; $\eta^{2}=0,228$; az artikulációs tempó esetén hang/s: $F(3,77)=6,664 ; p<0,001$; $\eta^{2}=0,208$; szótag/s: $F(3,77)=25,428 ; p<0,001 ; \eta^{2}=0,501$; szó/perc: $F(3,77)=$ 6,$\left.211 ; p=0,001 ; \eta^{2}=0,197\right]$. Ugyanakkor a Tukey post hoc test szerint a beszédtempó a hang/s-os értéket tekintve csak a 17 évesek és a többi életkori csoport között különbözött szignifikánsan ( $\mathrm{p}<0,001$; illetve a 13 éveseknél $\mathrm{p}=0,001)$, a szótag/s-os és a szó/perces érték esetén a 6 és a 13 évesek $(p<0.001)$ és a 6 és 17 évesek között $(p<0,001$ és $p=0,001)$, illetve csak a szótag/s-os értéket tekintve a 9 és 17 évesek $(p<0,001)$ között volt szignifikáns a különbség. Az artikulációs tempóban teljesen eltérő esetekben mutatott szignifikáns különbséget a Tukey post hoc test: a hang/sos értéket tekintve a 6 és a 17 évesek között $(p=0,001)$, a szótag/s-os érték esetén a 9 és 17 évesek között $(p<0,001)$, míg a szó/percben mért tempóban a 6 és a 13 évesek $(p<0,001)$, illetve a 9 és a 13 évesek $(p<0,020)$ között.

\subsection{Tartalomösszegzés}

Hasonlóan a másik két beszédtípushoz a tartalomösszegzéskor is szignifikáns különbség volt az életkori csoportok között mind a beszédtempóban, mind az artikulációs tempóban. Ebben a beszédtípusban is a 6 évesek produkálták a leglassabb beszéd- és artikulációs tempót mindhárom mértékegységben megadva. Ugyanakkor váratlan eredmény volt, ebben a beszédtípusban a 17 évesek a 9 évesekhez nagyon hasonló artikulációs tempóval beszéltek a hang/s-ban és a szó/percben megadott értékek szerint. A szó/perces adatok alapján a 13 évesek, a hang/s-os és a szótag/s-os értékek szerint a 17 évesek produkálták a leggyorsabb beszéd- és artikulációs tempót. A mértékegységek szerepét mutatja az is, hogy amíg a hang/s-os átlagértékek szerint a 13 évesek lassabban beszéltek, mint a 9 évesek, addig a szó/perces átlagaik szerint gyorsabban.

A statisztikai elemzés szerint a beszédtempóban a hang/s esetén: $F(3,76)=5,060$; $p=0,003 ; \eta^{2}=0,166$; a szótag/s esetén: $F(3,77)=6,677 ; p<0,001 ; \eta^{2}=0,209$; a szó/perc esetén: $F(3,77)=3,144 ; p=0,030 ; \eta^{2}=0,110$; az artikulációs tempóban a hang/s esetén: $F(3,76)=5,183 ; p=0,003 ; \eta^{2}=0,170$; a szótag/s esetén: $F(1,79)$ $=15,902 ; p<0,001 ; \eta^{2}=0,386$; a szó/perc esetén: $F(3,77)=5,468 ; p=0,002$; $\eta^{2}=0,178$. Ugyanakkor a Tukey post hoc test szerint a beszédtempó a hang/s-os értéket tekintve csak a 6 és a 17 évesek között ( $p=0,001)$, a szótag/s-os érték esetén a 6 és a 13 évesek $(p=0,013)$, illetve a 6 és a 17 évesek $(p<0,001)$ között, míg a szó/perces értékben a 6 és a 13 évesek között $(\mathrm{p}=0,001)$ volt szignifikáns a különbség. Az artikulációs tempóban a hang/s-os értéket tekintve a 6 és a 9 évesek $(p=0,032)$ és a 6 és a 17 évesek $(p=0,002)$, a szótag/s-os érték esetén a 6 és a 9 évesek 
$(p=0,004)$, a 6 és a 13 évesek $(p<0,001)$, a 6 és a 17 évesek $(p<0,001)$; illetve a 9 és a 17 évesek $(p=0,022)$ között, míg a szó/perces értékben a 6 és a 13 évesek között $(p=0,001)$ volt statisztikailag kimutatható különbség.

Az életkori csoportok között a beszédtípus függvényében adatolt statisztikai különbségeket a 3. és a 4. táblázatban foglaltuk össze.

3. táblázat. Szignifikáns különbségek a beszédtempóban az életkori csoportok között a beszédtípus függvényében $(\mathrm{h} / \mathrm{s}=$ hang $/ \mathrm{s}, \mathrm{st} / \mathrm{s}=\mathrm{szótag} / \mathrm{s} ; \mathrm{sz} / \mathrm{p}=\mathrm{szó} / \mathrm{perc})$

\begin{tabular}{|l|l|l|l|l|l|l|l|l|l|l|l|l|l|l|}
\hline \multirow{5}{*}{} & & \multicolumn{3}{|c|}{6 évesek } & \multicolumn{3}{c|}{9 évesek } & \multicolumn{3}{c|}{13 évesek } & \multicolumn{3}{c|}{17 évesek } \\
\cline { 2 - 14 } & & $\mathrm{h} / \mathrm{s}$ & $\mathrm{st} / \mathrm{s}$ & $\mathrm{sz} / \mathrm{p}$ & $\mathrm{h} / \mathrm{s}$ & $\mathrm{st} / \mathrm{s}$ & $\mathrm{sz} / \mathrm{p}$ & $\mathrm{h} / \mathrm{s}$ & $\mathrm{st} / \mathrm{s}$ & $\mathrm{sz} / \mathrm{p}$ & $\mathrm{h} / \mathrm{s}$ & $\mathrm{st} / \mathrm{s}$ & $\mathrm{sz} / \mathrm{p}$ \\
\hline \multirow{5}{*}{ Interjú } & 6 évesek & & & & & & & & $\mathrm{X}$ & $\mathrm{X}$ & $\mathrm{X}$ & $\mathrm{X}$ & $\mathrm{X}$ \\
\hline & 9 évesek & & & & & & & & $\mathrm{X}$ & $\mathrm{X}$ & $\mathrm{X}$ & $\mathrm{X}$ & $\mathrm{X}$ \\
\hline & 13 évesek & & $\mathrm{X}$ & $\mathrm{X}$ & & $\mathrm{X}$ & $\mathrm{X}$ & & & & $\mathrm{X}$ & & \\
\hline & 17 évesek & $\mathrm{X}$ & $\mathrm{X}$ & $\mathrm{X}$ & $\mathrm{X}$ & $\mathrm{X}$ & $\mathrm{X}$ & $\mathrm{X}$ & & & & & \\
\hline \multirow{5}{*}{ Történet } & 6 évesek & & & & & & & & & $\mathrm{X}$ & $\mathrm{X}$ & & $\mathrm{X}$ \\
\hline & 9 évesek & & & & & & & & & & $\mathrm{X}$ & & \\
\hline & 13 évesek & & & $\mathrm{X}$ & & & & & & & $\mathrm{X}$ & & \\
\hline & 17 évesek & $\mathrm{X}$ & & $\mathrm{X}$ & $\mathrm{X}$ & & & $\mathrm{X}$ & & & & & \\
\hline \multirow{5}{*}{ Tartalom } & 6 évesek & & & & & & & & & $\mathrm{X}$ & $\mathrm{X}$ & & \\
\hline & 9 évesek & & & & & & & & & & & & \\
\hline & 13 évesek & & & $\mathrm{X}$ & & & & & & & & & \\
\hline & 17 évesek & $\mathrm{X}$ & & & & & & & & & & & \\
\hline
\end{tabular}

4. táblázat. Szignifikáns különbségek az artikulációs tempóban az életkori csoportok között a beszédtípus függvényében $(\mathrm{h} / \mathrm{s}=$ hang $/ \mathrm{s}, \mathrm{st} / \mathrm{s}=\mathrm{szótag} / \mathrm{s} ; \mathrm{sz} / \mathrm{p}=\mathrm{szó} / \mathrm{perc})$

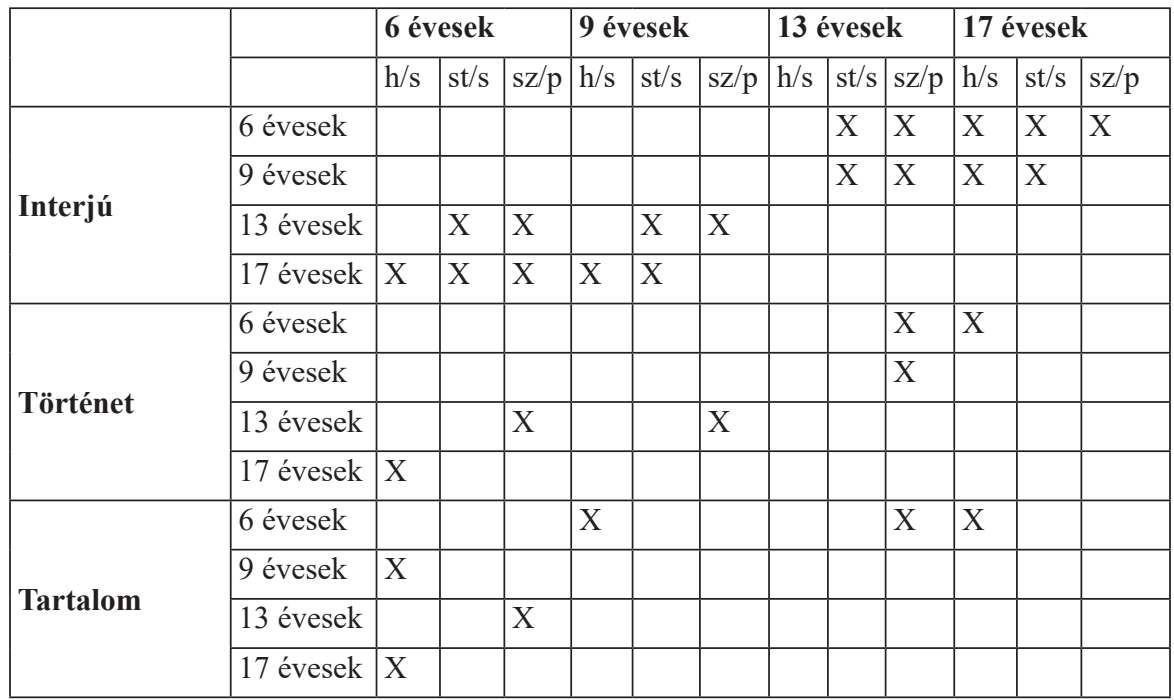




\subsection{A beszédtípusok közötti különbség}

Végezetül összevetettük ugyanazon életkori csoportokon belül a háromféle beszédtípusban mért tempóértékeket. A könnyebb átláthatóság érdekében az adatokat grafikonon is ábrázoltuk (1. és 2. ábra).

A 6 éveseknél a beszédtempóban egyik mértékegység esetén sem volt szignifikáns a különbség a beszédtípusok között. Az artikulációs tempót tekintve is csak a hang/s-os mértékegység esetében adatoltunk matematikailag kimutatható eltérést $\left[F(2,38)=4,899 ; p=0,013 ; \eta^{2}=0,205\right]$. A páronkénti összehasonlítás szerint az interjú és a történetmesélés $(p=0,030)$, illetve az interjú és a tartalomösszegzés $(p=0,035)$ között volt szignifikáns a különbség.

A 9 éveseknél szintén nem volt különbség a beszédtempóban a beszédtípusok között. Az artikulációs tempóban a 6 évesekhez hasonlóan náluk is csak a hang/s-ban mért értékek esetén volt szignifikáns az eltérés $[F(2,38)=9,916 ; p=0,001$; $\left.\eta^{2}=0,343\right]$, a páronkénti összehasonlítás a történetmesélés és az interjú $(p=0,005)$, illetve a történetmesélés és a tartalomösszegzés $(p=0,001)$ között mutatott szignifikáns különbséget.

A 13 éveseknél a statisztikai próba szignifikáns különbséget mutatott mind a beszédtempóban, mind az artikulációs tempóban a hang/s-os és a szótag/s-os érték esetén, míg a szó/percben egyik tempóértéket tekintve sem volt szignifikáns az eltérés [beszédtempó hang/s: $F(2,38)=6,692 ; p=0,005 ; \eta^{2}=0,260$; szótag/s: $F(2,38)=4,942 ; p=0,015 ; \eta^{2}=0,206$; artikulációs tempó hang/s: $F(2,38)=12,941$; $p<0,001 ; \eta^{2}=0,405 ;$ szótag/s: $\left.F(2,38)=4,978 ; p=0,012 ; \eta^{2}=0,208\right]$. A páronkénti összehasonlítás szerint a beszédtempóban az interjú és a tartalomösszegzés között volt szignifikáns a különbség mindkét mértékegység szerint (hang/s: $p=0,004$; szótag/s: $p=0,007)$. Az artikulációs tempóban a hang/s-os érték szerint az interjú és a történetmesélés $(p=0,011)$, illetve az interjú és a tartalomösszegzés $(p<0,001)$ között, míg a szótag/s-os érték szerint az interjú és a tartalomösszegzés $(p=0,015)$ között volt statisztikailag kimutatható eltérés.

A 17 éveseknél mindhárom mértékegység szerint szignifikáns különbség volt a beszédtempóban a beszédtípusok között, míg az artikulációs tempóban csak a hang/ s-ban és a szótag/s-ban mért értékek esetén [beszédtempó hang/s: $F(2,38)=12,192$; $p<0,001 ; \eta^{2}=0,391$; szótag/s: $F(2,38)=10,803 ; p<0,001 ; \eta^{2}=0,362$; szó/perc: $F(2,38)=6,141 ; p=0,006 ; \eta^{2}=0,244$; artikulációs tempó hang/s: $F(2,38)=15,852$; $p<0,001 ; \eta^{2}=0,455$; szótag/s: $\left.F(2,38)=16,286 ; p<0,001 ; \eta^{2}=0,462\right]$. A páronkénti összehasonlítás szerint a beszédtempóban az interjú és a tartalomösszegzés között szignifikáns volt a különbség mindhárom mértékegység szerint (hang/s: $p<0,001$; szótag/s: $p<0,001$; szó/perc: $p=0,012$ ). Emellett szignifikáns volt a különbség a hang/s-os értékekben az interjú és a történetmesélés között ( $p=0,027)$, a szótag/sos értékekben pedig a történetmesélés és a tartalomösszegzés között $(p=0,049)$. Az artikulációs tempóban a hang/s-os érték szerint az interjú és a történetmesélés $(p=0,007)$, illetve az interjú és a tartalomösszegzés $(p<0,001)$ között, míg a szótag/sos érték szerint az interjú és a tartalomösszegzés $(p<0,001)$, valamint a történetmesélés és a tartalomösszegzés $(p=0,034)$ között volt statisztikailag kimutatható eltérés. 

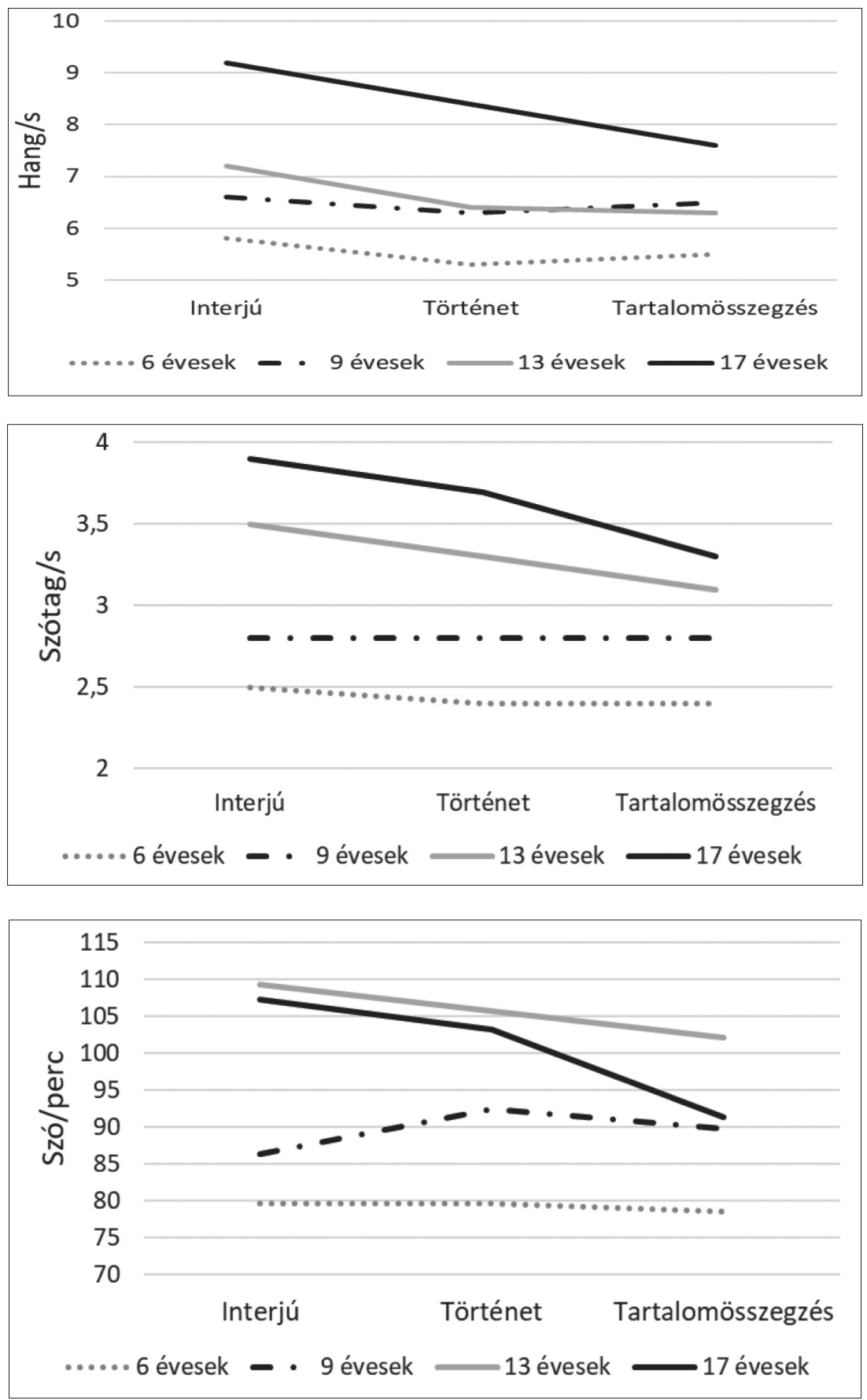

1. ábra. A beszédtempó átlagos értékei az egyes beszédtípusokban az életkor függvényében 

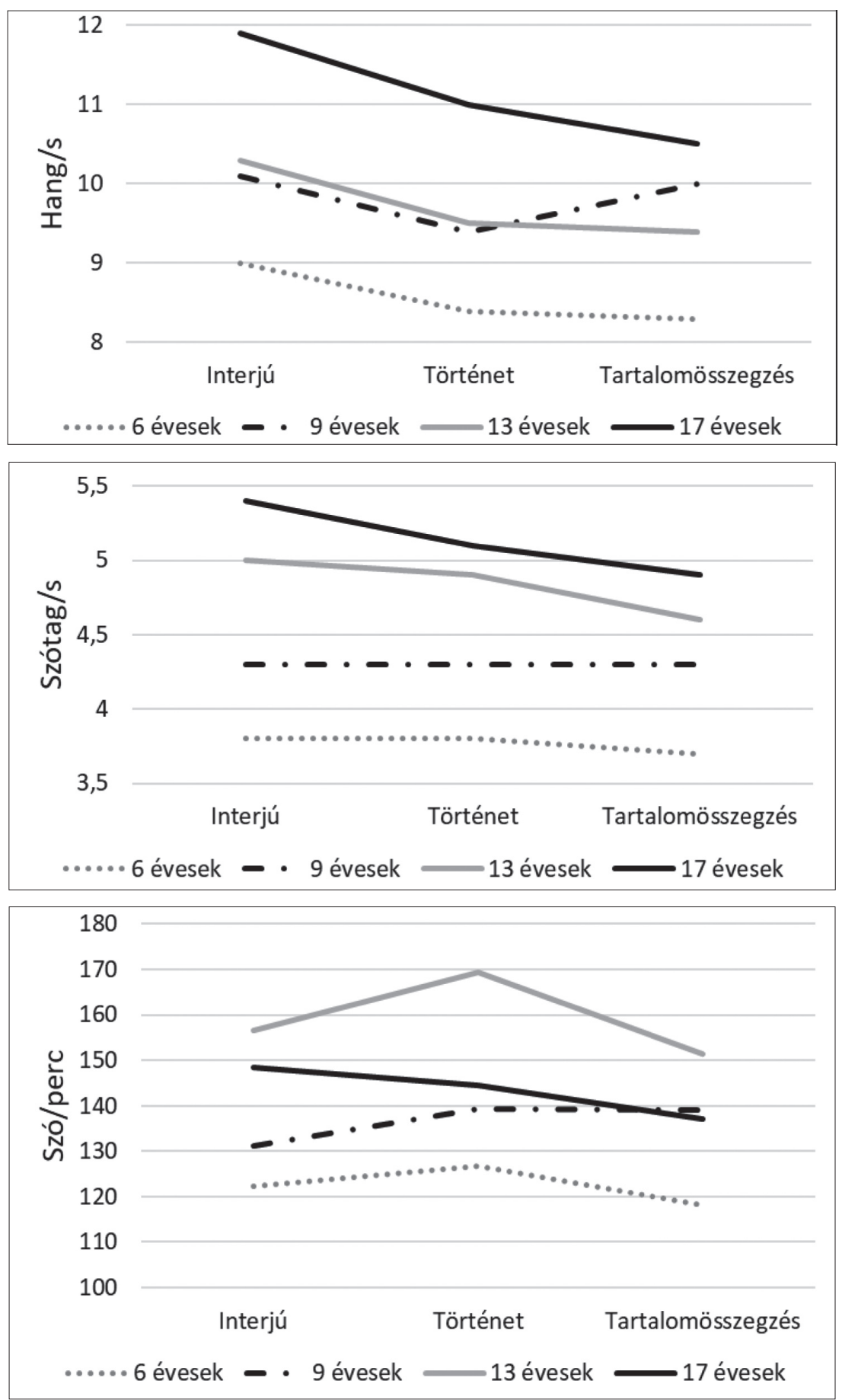

2. ábra. Az artikulációs tempó átlagos értékei az egyes beszédtípusokban az életkor függvényében 


\section{Következtetések}

Kutatásunkban 6, 9, 13 és 17 éves gyermekek és kamaszok beszédének temporális sajátosságait elemeztük háromféle beszédhelyzetben: interjúban, képsor alapján való történetmondáskor és egy hallott szöveg tartalmának összegzésekor. Azt feltételeztük, hogy a felnőttekhez hasonlóan az életkor és a beszédtípus is hatással lesz a beszédtempóra és az artikulációs tempóra. A vizsgálatunk egy másik fontos eleme volt, hogy a tempóértékeket háromféleképpen számítottuk ki: hang/s-ban, szótag/s-ban és szó/percben.

Az első hipotézisünk, amely szerint az életkor hatással lesz mindegyik beszédtípus beszédtempójára és artikulációs tempójára, méghozzá úgy, hogy minél idősebbek a beszélők, annál gyorsabb lesz a tempó, csak részben igazolódott. Egyrészt valóban a legfiatalabb beszélök beszéltek átlagosan a leglassabban mindegyik beszédtípusban és mértékegység szerint, másrészt viszont nem igazolódott, hogy a legidösebb csoport tempóértékei lennének minden beszédtípusban és mértékegység esetén a leggyorsabbak. A statisztikai elemzés még a 6 évesek és a 17 évesek között sem igazolt mindegyik beszédtípus és mértékegység esetén szignifikáns különbséget a tempóértékekben. Általánosságban azonban elmondható, hogy a 6 és 9 évesek tempói, illetve a 13 és 17 évesek tempói hasonlítottak egymáshoz a legjobban.

A második hipotézis a beszédtípus hatására vonatkozott, miszerint a tempóértékeket különbözőképpen befolyásolják a beszédtípusok a kisebb gyermekeknél és a kamaszoknál. Ez a hipotézisünk is csak részben igazolódott, függött az életkortól és a tempószámítás mértékegységétől is. A szó/perces értékben például egyáltalán nem volt szignifikáns különbség a beszédtípusok között egyik tempóértékben sem a 6, a 9 és a 13 éveseknél és a 17 évesek artikulációs tempójában sem. Ugyanakkor a hang/s-os értékben mindegyik életkorban szignifikáns eltérést mutattak a beszédtípusok az artikulációs tempót tekintve. A legtöbb különbség az interjú és a tartalomösszegzés között volt, ennek a hátterében a két feladat nehézsége közötti eltérés állhat. A tempóértékeket és a mértékegységeket együttesen tekintve megállapítható, hogy a kisebb gyermekeknél még nem vagy csak kismértékben meghatározó a beszédtípus a beszéd- és az artikulációs tempó tekintetében. Ez inkább 13 éves kor körül lesz befolyásoló tényező. Úgy tünik, hogy a nagyobb kamaszoknak a felnőttekhez hasonlóan könnyedén ment a saját életükröl való mesélés, ugyanakkor nehézséget okozott számukra a hallott szöveg visszamondása. Elképzelhető, hogy ez utóbbinak az oka az volt, hogy szerettek volna jobban megfelelni a feladatnak, vagy kevésbé volt ismerős számukra a feladat. A gyermekek ezzel ellentétben hasonlóan folyamatosan és nagyjából azonos tempóban mondták vissza a szöveget, mint ahogyan magukról meséltek. Az eredmények azzal magyarázhatók, hogy a gyermekek számára a mesehallgatás és a történetmesélés ismerős, mindennapos dolog, ugyanakkor ismeretlen szituáció egy (szinte idegen) felnőttnek mesélni a mindennapjaikról. A képsorozat és a hallott mese felidézése nagy segítséget nyújtott a komplex, hoszszabb összefüggő beszéd létrehozásához.

Végezetül adataink nagyon fontos módszertani kérdésre hívják fel a figyelmet a harmadik hipotézisünket is ezzel kapcsolatban fogalmaztuk meg. Nem mindegy 
ugyanis, hogy milyen mértékegységet választunk a tempóméréshez: nagyon különböző eredményekhez és következtetésekhez juthatunk általuk. Amíg az egyik mértékegységben kapott adatok között szignifikáns különbséget mértünk, mások között nem volt statisztikai eltérés sem az életkorok, sem a beszédtípusok tekintetében. Úgy tünik ez nyelvspecifikus jellemző is, mert amíg Amir és Grinfeld (2016) például a héberre vonatkozóan azt találta, hogy a hang/s és a szótag/s nagyon hasonló eredményeket mutat, addig a jelen vizsgálat adatai alapján ez nem jelenthető ki. Azt, hogy miért vannak ekkora különbségek a háromféle mértékegységben, nyelvi és artikulációs okokkal is magyarázhatjuk. Egyrészt befolyásoló lehet az adott beszédhelyzetben használt szavak hossza, szótagszáma stb. (bár ezek feltehetően hasonlóan egyenlítődnek ki mindegyik életkorban egy bizonyos szöveghossz után), másrészt az artikuláció pontossága (hány hangot ejt ki a beszélő valójában egy szótagból, milyen pontosan, milyen időtartamban valósítja meg az egyes hangokat, szótagokat, hogyan érvényesíti a koartikulációs szabályokat és a rövidülési tendenciákat stb.) is. Ezen tényezők további vizsgálatokat igényelnek. Összességében azonban fontos hangsúlyozni, hogy a mértékegység gondos megválasztása elengedhetetlen a különböző kutatási céloknak megfelelően.

A vizsgálatunknak több korlátja is van. Egyrészt bár 80 gyermek beszédének vizsgálata nagy adatközlöi számnak számít a fonetikai szakirodalomban, további gyermekek bevonásával pontosabb, általánosíthatóbb következtetésekre lehetne jutni. Másrészt érdemes lenne további paraméterek mentén is vizsgálni a beszédtípus hatását a gyermekek beszédére. Mindezek ellenére eredményeink újabb adalékokat szolgáltatnak az anyanyelv-elsajátítás különböző szakaszainak pontosabb megismeréséhez, a beszédtervezési stratégiák müködésének feltérképezéséhez a különböző életkorokban, illetve a módszertan kiválasztásának kérdésére is felhívják a figyelmet.

\section{SZAKIRODALOM}

Amir, Ofer - Grinfeld, Doreen 2011. Articulation rate in childhood and adolescence: Hebrew speakers. Language and Speech 54/2: 225-240. https://doi. org/10.1177/0023830910397496

Andrews, Gavin - Ingham, Roger J. 1971. Stuttering: Considerations in the evaluation of treatment. British Journal of Disorders of Communication 6/2: 427-9.

Aoyama, Katsura - Akbari, Christina - Flege, James E. 2016. Prosodic characteristics of American English in school-age children. In: Barnes, Jon - Brugos, Alejna - ShattuckHufnagel, Stefanie - Veilleux, Nanette (eds.): Proceedings of Speech Prosody. Boston, 572-6. https://doi.org/10.21437/SpeechProsody.2016-117

Auszmann Anita 2016. Magyar gyermekek magánhangzóinak akusztikai-fonetikai jellemzöi. Doktori értekezés. Eötvös Loránd Tudományegyetem, Budapest.

Balázs Boglárka - Bóna Judit 2016. Életkori sajátosságok a beszédképzésben és a beszédfeldolgozásban. In: Bóna Judit (szerk.): Fonetikai olvasókönyv. ELTE BTK Fonetikai Tanszék, Budapest, 7-19.

Boersma, Paul - Weenink, David 2008. Praat: doing phonetics by computer (Version 5.0.1). http://www.fon.hum.uva.nl/praat/download_win.html. (Letöltés ideje: 2021. január 21.)

Bóna Judit 2009. A gyors beszéd: Produkciós és percepciós sajátosságok. Lexika Kiadó, Budapest. 
Bóna Judit 2015. Különböző beszédtípusok temporális sajátosságai az életkor és a nem függvényében. Magyar Nyelvőr 139: 201-13.

Bóna Judit 2017. GABI - Gyermeknyelvi beszédadatbázis a kutatásban. In: Bóna, Judit (szerk.) Új utak a gyermeknyelvi kutatásokban. ELTE Eötvös Kiadó, Budapest, 35-50.

Chon, HeeCheong - Sawyer, Jean - Ambrose, Nicoline G. 2012. Differences of articulation rate and utterance length in fluent and disfluent utterances of preschool children who stutter. Journal of Communication Disorders 45/6: 455-67. https://doi.org/10.1016/j. jcomdis.2012.08.003

Deputy, Paul N. - Nakasone, Hirotaka - Tosi, Oscar 1982. Analysis of pauses occuring in the speech of children with consistent misarticulations. Journal of Communication Disorders 15/1: 43-54. https://doi.org/10.1016/0021-9924(82)90043-0

Flipsen, Peter, Jr. 2002. Longitudinal changes in articulation rate and phonetic phrase length in children with speech delay. Journal of Speech, Language, and Hearing Research 45/1: 100-10. https://doi.org/10.1044/1092-4388(2002/008)

Flipsen, P., Jr. 2006. Syllables per word in typical and delayed speech acquisition. Clinical Linguistics and Phonetics 20/4: 293-301. https://doi.org/10.1080/02699200400024855

Gósy Mária 1997. A magyar beszéd tempója és a beszédmegértés. Magyar Nyelvör 121: 129-39.

Gósy Mária 2004. Fonetika, a beszéd tudománya. Osiris Kiadó, Budapest.

Gyarmathy Dorottya - Horváth Viktória 2019. Characteristics of silent pauses in the spontaneous speech of kindergarten and primary school children. In: Bátyi Szilvia (szerk.): A nyelv - tanitás, tanulás, reprezentáció, feldolgozás. Pszicholingvisztikai tanulmányok 6. Language - teaching, learning, representation, processing. Studies in Psycholinguistics 6. Pannon Egyetem Modern Filológiai és Társadalomtudományi Kar, Veszprém, 190-208.

Hall, Kelly D. - Amir, Ofer - Yairi, Ehud 1999. A longitudinal investigation of speaking rate in preschool children who stutter. Journal of Speech, Language, and Hearing Research 42/6: 1367-77. https://doi.org/10.1044/jslhr.4206.1367

Henry, Lucy A. 1994. The relationship between speech rate and memory span in children. International Journal of Behavioral Development 17/1: 37-56. https://doi. org $/ 10.1177 / 016502549401700103$

Horváth Viktória 2013. Temporális szerveződés kilencéves gyermekek spontán beszédében. Beszédkutatás 21: 144-59.

Horváth Viktória 2016. Kisiskolás gyermekek spontán beszédének jellemzői. Alkalmazott Nyelvtudomány 16/1. doi:http://dx.doi.org/10.18460/ANY.2016.1.002

Jacewicz, Ewa - Fox, Robert Allen - Wei, Lai 2010. Between-speaker and within-speaker variation in speech tempo of American English. The Journal of the Acoustical Society of America 128/2: 839-50. https://doi.org/10.1121/1.3459842

Johnson, Wendell - Darley, Frederic L. - Spriestersbach, Duane C. 1963. Diagnostic methods in speech pathology. Harper and Row, New York.

Juncos-Rabadán, Onésimo-Pereiro, Arturo X. 2000. Telling stories in the elderly. Influence of attentional and working memory proceses (preliminary study). Psycholinguistics on the threshold of the year, 155-9.

Krepsz Valéria 2016. Fonetikai hasonlóságok és különbözőségek a beszédtípusokban. In: Bóna Judit (szerk.): Fonetikai olvasókönyv. ELTE BTK Fonetikai Tanszék, Budapest, 175-88.

Lackó, Mária 1991. The interrelation of articulation rate and pauses in children's speech. In: Gósy, Mária (ed.): Temporal Factors in Speech. A collection of papers. HAS Research Institute for Linguistics, Budapest, 139-51.

Laczkó Mária 2009. Középiskolai tanulók spontán beszédének temporális jellegzetességei. Magyar Nyelvör 133: 447-67. 
Markó Alexandra 2005. A temporális szerkezet jellegzetességei eltérő kommunikációs helyzetekben. Beszédkutatás 13: 63-77.

Markó Alexandra 2014. A beszéd temporális szerkezete a beszédmód és a beszédhelyzet függvényében. In: Bátyi Szilvia - Navracsics Judit - Vígh-Szabó Melinda (szerk.): Nyelvelsajátitási-, nyelvtanulási- és beszédkutatások. Pszicholingvisztikai tanulmányok IV. Gondolat Kiadó-Pannon Egyetem MFTK, Budapest-Veszprém, 33-45.

Neuberger Tilda 2014. A spontán beszéd sajátosságai gyermekkorban. Beszéd - Kutatás Alkalmazás 4. ELTE Eötvös Kiadó, Budapest.

Nip, Ignatius S. B.-Green, Jordan R. 2013. Increases in cognitive and linguistic processing primarily account for increases in speaking rate with age. Child Development $84 / 4$ : 1324 37. https://doi.org/10.1111/cdev.12052

Redford, Melissa A. 2015. The acquisition of temporal patterns. In: Redford, Melissa (ed.): The handboook of speech production. John Wiley \& Sons, Hoboken, NJ., 379-403. https:// doi.org/10.1002/9781118584156.ch17

Roodenrys, Steven - Hulme, Charles - Brown, Gordon 1993. The development of shortterm memory span: Separable effects of speech rate and long-term memory. Journal of Experimental Child Psychology 56/3: 431-42. https://doi.org/10.1006/jecp.1993.1043

Ryan, Bruce P. 1992. Articulation, language, rate, and fluency characteristics of stuttering and nonstuttering preschool children. Journal of Speech, Language, and Hearing Research 35/2. 333-42. https://doi.org/10.1044/jshr.3502.333

St. Louis, Kenneth O. - Schulte, Katrin 2011. Defining cluttering: the lowest common denominator. In: Ward, David-Scott, Kathleen Scaler (eds.): Cluttering. A handbook of research, intervention and education. Psychology Press, Hove-New York, 233-53.

Tumanova, Victoria - Zebrowski, Patricia M. - Throneburg, Rebecca N. - Kayikci, Mavis E. Kulak 2011. Articulation rate and its relationship to disfluency type, duration, and temperament in preschool children who stutter. Journal of Communication Disorders 44/1: 116-29. https://doi.org/10.1016/j.jcomdis.2010.09.001

Vakula Tímea 2020. A beszédprodukció és a beszédpercepció fejlödése 5-7 éves korban. ELTE Eötvös Kiadó, Budapest.

Vakula Tímea - Krepsz Valéria 2018. Egyéni sajátosságok vizsgálata a spontán beszéd temporális szerkezetében. In: Magyari Sára - Bartha Krisztina (szerk.): Nyelv - nyelvközösség - közösségi perspektiva. Partium Kiadó, Nagyvárad, 45-58.

Váradi Viola 2010. A felolvasás és a spontán beszéd temporális sajátosságainak összehasonlítása. Beszédkutatás 18: 100-9.

Váradi Viola 2011. A felolvasás és a spontán beszéd összevetésének pedagógiai vonatkozásai. Anyanyelv-pedagógia 4/4. http://www.anyp.hu/cikkek.php?id=343. (Letöltés ideje: 2021. január 21.)

Vorperian, Houri K. - Kent, Ray D. 2007. Vowel acoustic space development in children: a synthesis of acoustic and anatomic data. Journal of Speech, Language, amd Hearing Research 50/6: 1510-45. https://doi.org/10.1044/1092-4388(2007/104)

Walker, Jean F. - Archibald, Lisa M. 2006. Articulation rate in preschool children: a 3-year longitudinal study. International Journal of Language \& Communication Disorders 41/5: 541-565. https://doi.org/10.1080/10428190500343043

\section{Bóna Judit \\ egyetemi docens}

ELTE BTK Alkalmazott Nyelvészeti és Fonetikai Tanszék

https://orcid.org/0000-0003-2369-1636
Váradi Viola

nyelvész

ELTE BTK Alkalmazott Nyelvészeti

és Fonetikai Tanszék

https://orcid.org/0000-0001-7984-1387 


\begin{abstract}
SUMMARY
Speech rate and articulation rate in the speech of children and adolescents depending on speech tasks and units of measurement

Bóna, Judit-Váradi, Viola

The study examines speech rate and articulation rate in 6-, 9-, 13-, and 17-year-old speakers in three types of tasks (interview, storytelling based on a series of pictures, and summarizing the content of a heard text). The tempo values are presented and compared in several ways: sound/s, syllable/s, and word/minute. Results show that although age has an effect on speech and articulation rate, its effect is not present in all speech tasks and for all tempo values. The effect of speech tasks on tempo values was significant from the age of 13 on. However, it is also important which unit the tempo values are given in: they can lead to quite different results and therefore different conclusions. While we measured significant differences between the data obtained in one unit, there were no statistical differences across age groups or speech tasks in the other units. Our data enrich the knowledge related to first language acquisition with new results on the one hand, and draw attention to an important methodological issue, namely the importance of units of measurement, on the other hand.
\end{abstract}

Keywords: speech rate, articulation rate, speech task, units of measurement, children

\title{
A beszélőn belüli variabilitás alakulása a beszédtípus, a szövegbeli helyzet és az életkor mentén
}

\section{Bevezetés}

Az öregedő nyugati társadalmakban a kor észlelése és a kapcsolódó sztereotípiák megvitatása kulcsfontosságú tényezők, amelyek befolyásolják a nemzedékek közötti sikeres kommunikációt. A beszédben megjelenő idősödés (legyen az bármely fiatal vagy idős korban) folyamatával kapcsolatos érdeklődés megjelenése egészen a '60-as évekre vezethetö vissza, amikor is Ptacek és Sander (1966) kísérleti eredményei szerint a lehallgatók 78\%-ban helyesen meg tudják mondani, hogy a lejátszott magánhangzókat idős vagy fiatal beszélők produkálták-e. Az olvasás alapján történő megítéltetés esetében ez az arány 99\%-os volt. Egy másik kutatás hasonló eredményekről számol be a produkció és a percepció oldalát egyidejüleg figyelembe véve: az artikulációs tempó az életkor előrehaladtával lassul, és a lassabb tempójú beszélőket idősebbnek ítélik meg, ez a tendencia azonban csak a felolvasásban volt kimutatható, a spontán beszédben nem találtak ilyen irányú összefüggést a tempó, a valódi és a becsült életkor között (Brückl-Sendlmeier 2003).

A humánlehallgatás jó teljesítménye számos kérdést vet fel arra vonatkozóan, hogy vajon hogyan (és) mely paraméterek mentén képesek meghatározni a beszélök 